\title{
Yirmi yaşında erkek hastada çok sayıda asemptomatik skrotal nodüller
}

Yasemin YUYUCU KARABULUT, Engin ŞENEL, Asım USLU

Yirmi yaşındaki erkek hasta yaklaşık on yıldır skrotumunda mevcut olan ağrısız şişlikler nedeniyle Deri ve Zührevi Hastalıklar polikliniğine başvurdu. Dermatolojik incelemede skrotumda çok sayıda, iyi sınırlı, hassas olmayan, sert subkutan nodüller gözlendi (Şekil 1). Sistemik, metabolik, endokrin hastalık ve ilaç kullanım öyküsü bulunmayan hasta, skrotumda travma ve enfeksiyöz hastalık da bildirmedi. Kalsiyum, fosfor ve parathormon içeren laboratuvar tetkik sonuçları normal olarak saptandı. Hastanın isteği üzerine büyük lezyonlar plastik cerrahi bölümünce eksize edilerek patoloji bölümüne histopatolojik inceleme için gönderildi (Şekil 2 ve 3).

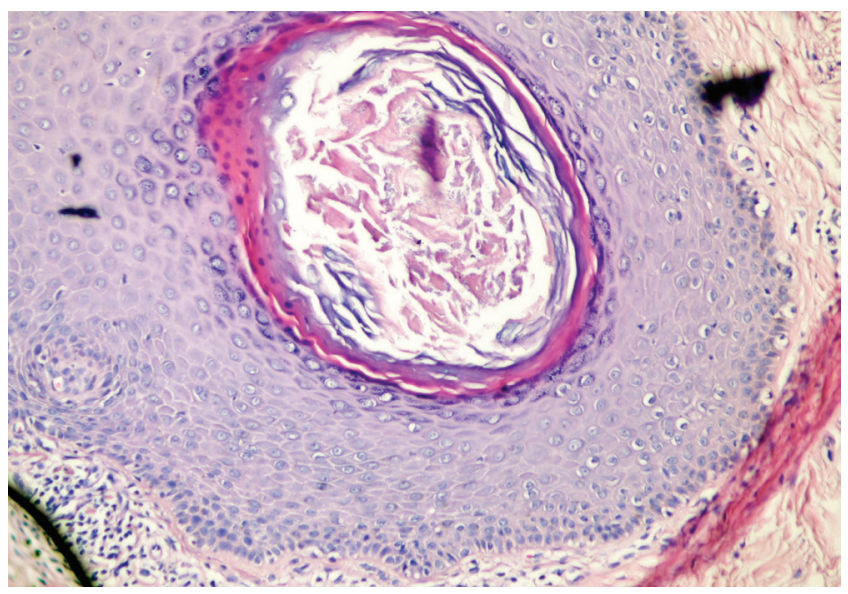

Şekil 2. Keratin içeriğinde kalsifikasyon gösteren epidermal inklüzyon kisti (H\&E, x100)

Engin Şenel (四)

Dermatoloji Anabilim Dall, Tip Fakültesi, Hitit Üniversitesi, Çorum, Türkiye

e-mail: enginsenel@enginsenel.com

Yasemin Yuyucu Karabulut

Patoloji Anabilim Dall, Tip Fakültesi, Mersin Üniversitesi, Mersin, Türkiye Asım Uslu

Plastik Cerrahi Kliniği, Çankırı Devlet Hastanesi, Çankırı, Türkiye

Gönderilme: 13.11.2014

Kabul: 17.12.2014

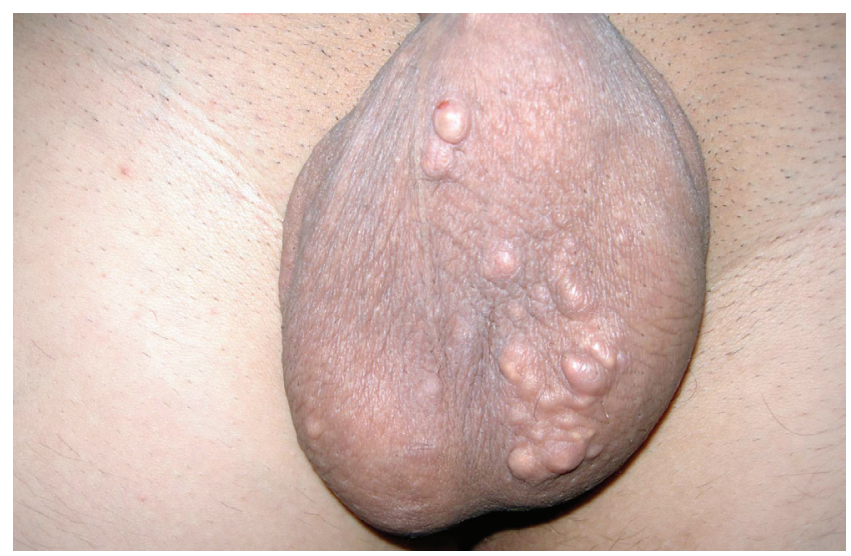

Şekil 1. Skrotumda multiple nodüller

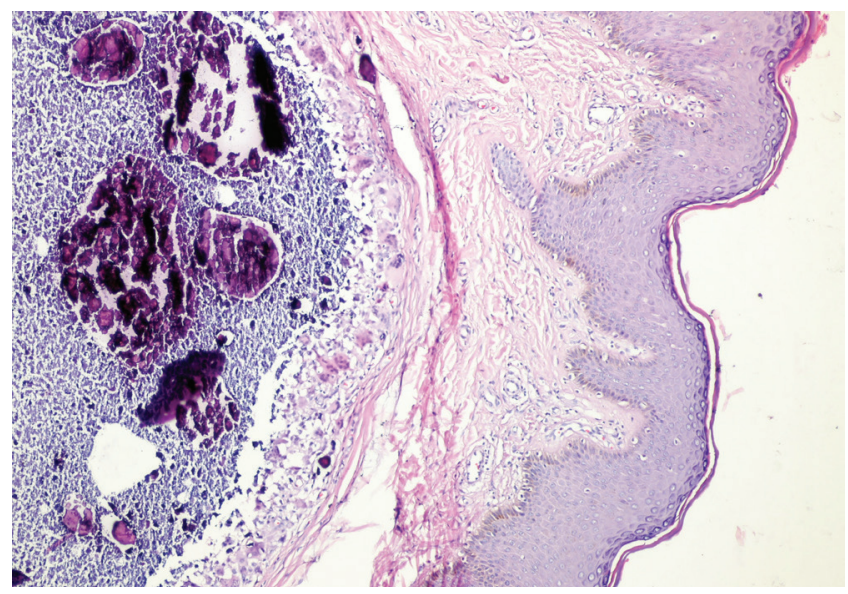

Şekil 3. Granülomatöz yabancı cisim reaksiyon ve yoğun fibrozis ile çevrelenmiş subepidermal kalsifik kitleler (H\&E, 100) 


\section{Tanınız nedir?}

\section{Tanı: İdiyopatik skrotal kalsinozis}

İdiyopatik skrotal kalsinozis, skrotum derisinde çok sayıda, asemptomatik nodüllerle karakterli oldukça nadir görülen benign deri hastalığıdır [1,2]. Çocuk ve genç erişkin dönemde görülür, lezyonlar sayı ve boyut olarak artma eğilimi gösterir. Mikroskobik olarak amorf bazofilik kitleler şeklinde izlenir ve sıklıkla lezyona yabancı cisim reaksiyonu eşlik eder $[3,4]$. İdiyopatik skrotal kalsinozis, ilk olarak 1888'de Hutchinson tarafindan tanımlanmıştır [3, 5]. Hastalığın etiyolojisi tam olarak belli değildir [2]. Hastalarda herhangi bir biyokimyasal bozukluğa neden olan metabolik ve endokrin hastalık mevcut değildir. Ayırıcı tanıda skrotumun anjiokeratomu, steatokistoma multipleks, testiküler mikrolitiazis veya lökemiya kutis düşünülebilir. Cerrahi tedavi altın standarttır. Patolojik değerlendirmede epidermal kistten kalsifiye dermal nodüllere kadar değişen morfolojik spektruma sahiptir [4]. Lezyonun patogenezi ile ilgili farklı görüşler olmakla birlikte literatürdeki genel kabul, lezyonların basit epidermal kistler şeklide ortaya çıktığı zaman içerisinde, kistlerin rüptüre olup çevresinde yabanc1 cisim tipi iltihap ve granülasyon dokusu oluşturduğu ve bu odaklarda distrofik kalsifikasyon geliştiği yönündedir $[5,6]$.

\section{Kaynaklar}

1. Parlakgumus A, Canpolat ET, Caliskan K, et al. Scrotal calcinosis due to resorption of cyst walls: a case report. Journal of Medical Case Reports 2008;2:375 doi: 10.1186/1752-19472-375.

2. Shah V, Shet T. Scrotal calcinosis results from calcification of cysts derived from hair follicles: a series of 20 cases evaluating the spectrum of changes resulting in scrotal calcinosis. Am J Dermatopathol 2007;29:172-5. doi: 10.1097/01. dad.0000246465.25986.68.

3. Karaca M, Taylan G, Akan M, Eker G, Gideroglu K, Gul AE. Idiopathic scrotal calcinosis: surgical treatment and histopathologic evaluation of etiology. Urology 2010;76:14935. doi: 10.1016/j.urology.2010.02.001.

4. Song DH, Lee KH, Kang WH. Idiopathic calcinosis of the scrotum: histopathologic observations of fifty-one nodules. J Am Acad Dermatol 1988;19:1095-101

5. Sarma DP, Weilbaecher TG. Scrotal calcinosis: calcification of epidermal cysts. J Surg Oncol 1984;27:76-9.

6. Michl UH, Gross AJ, Loy V, Dieckmann KP. Idiopathic calcinosis of the scrotum--a specific entity of the scrotal skin. Case report. Scand J Urol Nephrol 1994;28:213-7. 